\title{
Kan kostholdsdata fra hjerte-karundersøkelsene i Finnmark, Sogn og Fjordane og Oppland brukes i analyser av andre sykdommer enn hjerte-karsykdom?
}

\author{
Elin Bjørge Løken og Kari Solvoll \\ Institutt for ernceringsforskning, Universitetet i Oslo \\ Korrespondanse: Elin Bjørge Løken, Institutt for ernæringsforskning, Universitetet i Oslo, Postboks 1046 Blindern, 0316 Oslo \\ telefon 22851371 fax 22851398 e-mail: e.b.loken@basalmed.uio.no
}

\begin{abstract}
SAMMENDRAG
Et selvadministrert spørreskjema om utvalgte sider av det vanlige kostholdet er besvart av ca. 60000 menn og kvinner i de tre første hjerte-karundersøkelsene i Finnmark, Sogn og Fjordane og Oppland (1974-1988). Sammenligning av kostdata hos et utvalg av deltakerne som både besvarte spørreskjemaet og et 24 timers kostintervju, har vist at spørreskjemaet ikke bare ga et brukbart bilde av forbruket av melk, brød, smør/margarin og kaffe, men også for beregnet inntak av energi, protein, fett og kalsium. Skjemaet inneholdt få spørsmål om friske plantematvarer og kan derfor ikke gi data for inntak av antioksidanter. Resultatene viste klare forskjeller i kostholdet mellom menn og kvinner og i forhold til bosted. Videre analyser har vist statistisk signifikante sammenhenger mellom en eller flere kostkomponenter og risiko for ulike typer kreft og lårhalsbrudd. Materialet omfatter en forholdsvis ung kohorte, og kan på sikt være interessant for studier av andre sykdommer eller dødsårsaker som antas å ha sammenheng med en eller flere av de kostkomponentene som spørreskjemaet omfatter. Ved vurdering av resultatene er det viktig å ta hensyn til at spørreskjemaet ikke omfattet det totale kostholdet.
\end{abstract}

Løken EB, Solvoll K. Can dietary data from the cardiovascular disease studies in Finnmark, Sogn og Fjordane and Oppland be used to analyse risk for other diseases? Nor J Epidemiol 1997; 7 (2): 191-200.

\section{ENGLISH SUMMARY}

A self-administered questionnaire covering selected aspects of the habitual diet was answered by approximately 60000 men and women who participated in the three first screenings of cardiovascular disease risk factors in the counties of Finnmark, Sogn og Fjordane and Oppland (1974-1988). A subsample of the subjects was in addition interviewed about their intake of foods and beverages on the day before the questionnaire was handed out. It appeared that the questionnaire not only provided reasonable data on consumption of milk, bread, butter/margarine and coffee, but also for calculated intake of energy, protein, fat and calcium. Since the dietary questionnaire had few questions on fresh produce it cannot provide estimates on antioxidants. The results showed clear differences in the diet of men and women and between counties. Further analyses have demonstrated statistically significant associations between one or more diet components and risk of breast cancer, colon cancer or hip fracture. Most of the associations were dose dependent. The dietary data from the countywide screenings of cardiovascular disease risk factors comprise a relatively young cohort and may in the future be used to analyse risk of other diseases or mortality that are associated with one or more of the dietary components included in the questionnaire. Results should be interpreted with care as the dietary questionnaire did not cover the entire diet.

\section{INNLEDNING}

Da Statens helseundersøkelser startet sine fylkesvise undersøkelser av risikofaktorer for hjerte- og karsykdom i Finnmark i 1974 var kartlegging av deltakernes kosthold ikke med i de opprinnelige planene. Etter en tids feltarbeid ble Avdeling for kostholdsforskning ved Universitetet i Oslo bedt om å lage noen få spørsmål som kunne bidra til å forklare den høye forekomsten av hjerte-karsykdom. Vi hadde liten erfaring med bruk 
av selvadministrerte spørreskjemaer på den tiden, men så dette som en god anledning til å prøve ut en slik metode. Det ble derfor enighet om at vi skulle lage et noe større spørreskjema, slik at flere sider av deltakernes vanlige kosthold kunne bli belyst, men uten at det ble lagt opp til tradisjonell næringsberegning av dataene.

Formålet med denne artikkelen er å diskutere om svarene på kostholdsskjemaet kan brukes til å studere sammenhenger mellom kosthold og andre sykdommer enn hjerte-karsykdom. Dette blir gjort med utgangspunkt i tre publiserte arbeider om brystkreft (1-3), ett arbeid om kreft i tykktarm (4), ett arbeid om bruk av kaffe i forhold til ulike typer kreft (5) og ett arbeid om lårhalsbrudd (6).

\section{MATERIALE}

Ved hjerte-karundersøkelsene i de tre pilotfylkene, Finnmark, Sogn og Fjordane og Oppland, ble alle som bodde i fylket og tilhørte aldersgruppen 35-49 år invitert til å delta, det samme gjaldt et mindre, randomisert utvalg i aldersgruppen 20-34 år. Undersøkelsen ble gjentatt med henholdsvis tre eller fem og ti års mellomrom. Undersøkelsene startet i Finnmark i 1974, tredje runde ble avsluttet i Oppland i 1988.

I første hjerte-karundersøkelse ble kostholdsskjemaet bare brukt i én kommune i Finnmark og i åtte kommuner i Sogn og Fjordane, mens samtlige kommuner var med i Oppland. I den andre undersøkelsen var det fem kommuner i Sogn og Fjordane som ikke fikk kostholdsskjemaet, mens samtlige kommuner i de tre fylkene var med i tredje undersøkelse.

For ikke å influere på frammøtet til hovedundersøkelsen ble kostholdsskjemaet først delt ut ved screeningen. Skjemaet ble besvart hjemme og returnert i en ferdig adressert og frankert konvolutt. Det ble foretatt en purring. I første runde kom ca. $95 \%$ av de utdelte skjemaene tilbake i utfylt stand, mens oppslutningen var noe lavere $\mathrm{i}$ andre og tredje runde. I alt er det kommet inn ca. 100000 besvarte skjema, og nærmere 60000 personer har vært med minst én gang. Materiale og metode for selve hjerte-karundersøkelsen er nærmere beskrevet av Bjartveit og medarbeidere (7).

I tillegg til dataene fra hjerte-karundersøkelsen er kostholdsdataene koblet til data fra Folkeregisteret med hensyn til sivilstatus og bosted, og de er senere blitt koblet til Kreftregisteret og til Statistisk sentralbyrås register over dødsårsaker. Kreftdiagnosene bygger på kliniske og patologiske rapporter fra alle landets sykehus og laboratorier. Forekomst av lårhalsbrudd blant dem som deltok i den andre undersøkelsen er blitt registrert fram til utgangen av 1990 ved gjennomgang av sykehusjournaler eller epikriser fra sykehusene $\mathrm{i}$ de tre fylkene. En oversikt over deltakerne $\mathrm{i}$ de publiserte studiene av kostvaner $\mathrm{i}$ forhold til forskjellige typer kreft og lårhalsbrudd er gitt i tabell 1.

\section{Kostholdssporreskjemaet}

Spørreskjemaet var på 4 sider og inneholdt opprinnelig 61 spørsmål med faste svaralternativ. Spørsmålene omfattet utvalgte sider av det vanlige kostholdet: type og mengde fett per brødskive, type og mengde brød og melk per dag, bruksfrekvens for ulike typer middagsmat, bruk av pålegg, drikke og en del andre matvarer. Noen spørsmål ble tatt ut fra første til andre undersøkelse, og noen nye kom til i tredje. De fleste spørsmålene og svaralternativene er imidlertid uendret. Det spørreskjemaet som ble brukt i den andre runden, er gjengitt som vedlegg.

Spørreskjemaets reproduserbarhet ble testet i 1982 ved å sammenligne svar fra 734 kvinner i Oppland som hadde besvart spørreskjemaet to ganger med en måneds mellomrom (8). For å supplere dataene fra spørreskjemaet og for å få mulighet til å sammenligne svarene på en del av dem, ble det i tillegg foretatt et personlig intervju om kosten det siste døgnet blant et tilfeldig utvalg av dem som møtte. I den første hjertekarundersøkelsen har vi opplysninger om kostholdet fra både spørreskjema og intervju for 1609 personer $i$ sju områder $(9,10)$. I de to neste undersøkelsene ble det tatt sikte på å reintervjue de samme personene fra bare ett av områdene $(11,12)$.

Etter initiativ fra Kreftregisteret er det forsøkt å estimere deltakernes inntak av energi og næringsstoffer ut fra svar på 31 av kostspørsmålene fra den andre hjerte-karundersøkelsen. Spørsmålene omfatter bruk av melk, poteter, brød, fem typer pålegg, smør på brød og til steking, sju middagsretter med kjøtt og fisk, kaker, egg, appelsiner, grøt, tran og vitamintilskudd. Inntaket er beregnet ved å multiplisere antall skiver, glass og andre mengdeenheter brukt per dag, uke eller måned med næringsinnholdet $\mathrm{i}$ en standardporsjon $\mathrm{i}$ følge opplysninger i den norske matvaretabellen (13). I de tilfelle frekvens og ikke mengde ble oppgitt, eller omvendt, ble manglende verdi erstattet av median frekvens eller mengde for det aktuelle spørsmål. Dersom ingen av delene var angitt, ble forbruket satt til null. En detaljert beskrivelse av framgangsmåten og de verdier som er brukt er gitt i en teknisk rapport (14).

\section{RESULTATER}

\section{Deltakernes kosthold}

Spørreskjemaene var gjennomgående godt utfylt. De fleste spørsmålene var besvart av $98-99 \%$ av deltakerne (se tabell 2). Vatten og medarbeidere forkastet 58 kostholdsskjema $(0,4 \%)$ av tekniske grunner i sine analyser $(1,2)$, mens Gaard og medarbeidere ekskluderte de som hadde besvart færre enn 20 spørsmål eller som fikk mindre enn $2100 \mathrm{~kJ}$ (500 kcal) per dag fra de beregnete matvarene. Dette gjaldt 552 personer, dvs. $2,1 \%(3,4)$.

Testing av spørreskjemaets reproduserbarhet viste god overenstemmelse for de aller fleste spørsmålene. 
Tabell 1. Oversikt over publiserte studier av sammenheng mellom kosthold og sykdomsrisiko.

\begin{tabular}{|c|c|c|c|c|c|}
\hline Sykdom & $\begin{array}{l}\text { Under- } \\
\text { søkelse }\end{array}$ & $\begin{array}{c}\text { Alder ved start } \\
\text { år }\end{array}$ & $\begin{array}{c}\text { Oppfolging }^{1} \\
\text { år }\end{array}$ & $\begin{array}{c}\text { Antall } \\
\text { deltakere }\end{array}$ & $\begin{array}{l}\text { Antall } \\
\text { kasus }^{2}\end{array}$ \\
\hline Brystkreft (Vatten et al. 1990 (1)) & I & $35-49$ & $11-14$ & $14593 \mathrm{~K}^{3}$ & $152 \mathrm{~K}$ \\
\hline Brystkreft (Vatten et al. 1990 (2)) & I & $35-49$ & $11-14$ & $14500 \mathrm{~K}$ & $152 \mathrm{~K}$ \\
\hline Brystkreft (Gaard et al. 1995 (3)) & II & $20-54$ & $7-13$ & $25892 \mathrm{~K}$ & $248 \mathrm{~K}$ \\
\hline Tykktarmskreft (Gaard et al. 1996 (4)) & II & $20-54$ & $7-13$ & $\begin{array}{l}25638 \mathrm{M} \\
24897 \mathrm{~K}\end{array}$ & $\begin{array}{l}83 \mathrm{M} \\
60 \mathrm{~K}\end{array}$ \\
\hline Ulike typer kreft (Stensvold et al. 1994 (5)) & II & $35-54$ & $8-12$ & $\begin{array}{l}21735 \mathrm{M} \\
21238 \mathrm{~K}\end{array}$ & \\
\hline munnhule-, spiserørkreft & & & & & $\begin{array}{l}33 \mathrm{M} \\
12 \mathrm{~K}\end{array}$ \\
\hline lungekreft & & & & & $\begin{array}{l}93 \mathrm{M} \\
32 \mathrm{~K}\end{array}$ \\
\hline ondartet føflekkreft & & & & & $\begin{array}{l}36 \mathrm{M} \\
48 \mathrm{~K}\end{array}$ \\
\hline Lårhalsbrudd (Meyer et al. 1997 (6)) & II & $36-56$ & $9-14$ & $\begin{array}{l}20035 \mathrm{M} \\
19752 \mathrm{~K} \\
\end{array}$ & $\begin{array}{l}157 \mathrm{~K} \\
56 \mathrm{M}\end{array}$ \\
\hline
\end{tabular}

1) Tid mellom screening og dato for avsluttet oppfølgingsperiode.

2) Krefttilfeller som var diagnostisert før undersøkelsen eller det året undersøkelsen ble utført, er utelatt i de fleste analysene (1-4). Det samme gjelder lårhalsbrudd som skyldtes trafikkulykke, fall fra høyere enn bakkenivå og beinkreft (6).

3) $\mathrm{K}=$ kvinner, $\mathrm{M}=$ menn.

Samsvaret mellom de to datasettene som ble samlet inn med en måneds mellomrom varierte fra $98 \%$ (søtpålegg) til 51\% (appelsiner). Medianen for de 55 spørsmålene som ble testet var $81 \%$. McNemars symmetritest viste at avvikene var tilfeldig fordelt for de aller fleste spørsmålene med unntak av bruk av leverpostei, kjøpt eller hjemmebakt brød, appelsiner og kjøttmiddager per uke.

Spørreskjemaet avdekket en del klare forskjeller i kostholdet mellom menn og kvinner og mellom fylkene, se tabell 2. Det ble også funnet forskjeller i forhold til alder, og blant dem som bodde i Finnmark ble det funnet visse forskjeller i forhold til etnisk bakgrunn (norsk, samisk eller finsk). Dette er nærmere beskrevet $\mathrm{i}$ egne rapporter (15-20).

Ved sammenligning av resultater fra spørreskjema og intervju ved første hjerte-karundersøkelse, ble det funnet at spørreskjemaet ga brukbar informasjon om bruk av melk, brød og kaffe, det vil si matvarer som blir brukt daglig. Personer som oppgav lave mengder i spørreskjemaet, oppgav ofte høyere inntak i intervjuet, mens de som oppgav høye mengder i spørreskjemaet hadde en tendens til å angi lavere inntak i intervjuet (10). Kostintervjuet var ikke egnet til å validere spørsmålene om bruk av kjøtt og fisk til middag. Det samme gjaldt matvarer som ble spist sjelden eller uregelmessig.

Tabell 3 viser at brødvarer, melk, ost, smør/margarin, kjøtt/fisk og poteter utgjorde en vesentlig del av kosten hos de kvinner som ble intervjuet i 1982 (11). Disse matvaregruppene utgjorde en noe større andel av kosten hos menn. Næringsberegning av de utvalgte opplysningene i spørreskjemaet ga gjennomsnittlig 70-
$80 \%$ av det totale inntaket som ble registrert i intervjuet med hensyn til energi, protein, fett og kalsium, noe mindre for kostfiber $(3,4,6)$. I følge intervjuet bidro poteter og frisk frukt med ca. $55 \%$ av tilførselen med vitamin C (tabell 3), mens beregning av spørreskjemaets opplysninger om bruk av poteter og appelsiner bare nådde opp i $35 \% \mathrm{av}$ intervjukostens innhold av vitamin $\mathrm{C}$.

\section{Brystkreft}

Vatten og medarbeidere analyserte svarene på de enkelte kostspørsmålene i forhold til risiko for å utvikle brystkreft for dem som deltok i første undersøkelse $(1,2)$. Det ble funnet en svak, men ikke statistisk signifikant, tendens til negativ sammenheng mellom høyt daglig forbruk av kaffe og risiko for brystkreft (minst fem kopper kaffe per dag sammenlignet med inntil to). Ved inndeling etter kroppsmasse (BMI) ble det funnet en signifikant, lineær negativ sammenheng for høyt forbruk av kaffe hos dem som hadde BMI < $24 \mathrm{~kg} / \mathrm{m}^{2}$, mens det var en positiv, ikke signifikant tendens hos dem som hadde BMI $>24 \mathrm{~kg} / \mathrm{m}^{2}$ (1). I tillegg ble det funnet en positiv, lineær og statistisk signifikant sammenheng mellom hyppig bruk av kjøtt til middag og risiko for brystkreft (minst fem middager med kjøtt per uke sammenlignet med inntil to). Det ble også funnet en negativ og statistisk signifikant sammenheng for dem som brukte kokt fisk minst fem ganger per måned sammenlignet med dem som hadde inntil to slike middager per måned. Noen sammenheng for totalt antall fiskemiddager ble imidlertid ikke funnet (2). 
Tabell 2. Svar på noen spørsmål i kostholdsskjemaet. Prosent av menn og kvinner $\geq 35$ år i Finnmark II, Sogn og Fjordane II og Oppland II ${ }^{1}$.

\begin{tabular}{|c|c|c|c|c|c|c|}
\hline & \multicolumn{3}{|c|}{ Menn } & \multicolumn{3}{|c|}{ Kvinner } \\
\hline & $\begin{array}{c}\text { Finnmark } \\
\mathrm{n}=5744\end{array}$ & $\begin{array}{c}\text { Sogn+Fj } \\
n=4641 \\
\end{array}$ & $\begin{array}{c}\text { Oppland } \\
\mathrm{n}=11975\end{array}$ & $\begin{array}{c}\text { Finnmark } \\
\mathrm{n}=5375\end{array}$ & $\begin{array}{c}\text { Sogn+Fj } \\
\mathrm{n}=4445\end{array}$ & $\begin{array}{c}\text { Oppland } \\
\mathrm{n}=12365\end{array}$ \\
\hline \multicolumn{7}{|l|}{ BRØD, skiver/dag } \\
\hline mindre enn 2 & 2 & 1 & 1 & 8 & 3 & 5 \\
\hline $2-4$ & 22 & 12 & 15 & 57 & 52 & 61 \\
\hline $5-6$ & 37 & 32 & 35 & 27 & 35 & 28 \\
\hline $7-8$ & 26 & 34 & 33 & 6 & 8 & 5 \\
\hline $9-12$ & 11 & 18 & 15 & 1 & 1 & 1 \\
\hline 13 eller flere & 2 & 3 & 1 & - & - & - \\
\hline ubesvart & 1 & 1 & 1 & 1 & 1 & 1 \\
\hline \multicolumn{7}{|l|}{ SMØR/MARGARIN, g/skive } \\
\hline bruker ikke noe & 4 & 5 & 5 & 10 & 17 & 19 \\
\hline 3 & 37 & 43 & 45 & 54 & 53 & 57 \\
\hline 5 & 30 & 31 & 30 & 20 & 18 & 15 \\
\hline 8 & 17 & 13 & 12 & 6 & 4 & 3 \\
\hline 12 & 8 & 5 & 4 & 3 & 1 & 1 \\
\hline ubesvart & 5 & 4 & 3 & 8 & 7 & 6 \\
\hline \multicolumn{7}{|l|}{ MELK, glass/dag } \\
\hline drikker ikke melk/mindre enn 1 & 12 & 16 & 8 & 20 & 26 & 17 \\
\hline 1 & 14 & 15 & 13 & 26 & 26 & 27 \\
\hline 2 & 24 & 28 & 22 & 30 & 30 & 32 \\
\hline 3 & 20 & 18 & 22 & 14 & 11 & 15 \\
\hline 4 & 17 & 13 & 20 & 6 & 4 & 6 \\
\hline 5 eller flere & 12 & 8 & 15 & 2 & 1 & 2 \\
\hline ubesvart & 1 & 2 & 1 & 2 & 3 & 2 \\
\hline \multicolumn{7}{|l|}{ KAFFE, kopper/dag } \\
\hline drikker ikke kaffe /mindre enn 1 & 2 & 5 & 5 & 2 & 3 & 4 \\
\hline $1-2$ & 4 & 10 & 10 & 6 & 10 & 11 \\
\hline $3-4$ & 16 & 29 & 29 & 25 & 38 & 38 \\
\hline $5-6$ & 27 & 32 & 30 & 32 & 34 & 31 \\
\hline $7-8$ & 24 & 15 & 16 & 20 & 11 & 11 \\
\hline 9 eller flere & 27 & 8 & 8 & 15 & 4 & 5 \\
\hline ubesvart & 1 & 1 & 1 & 1 & 1 & 1 \\
\hline \multicolumn{7}{|l|}{ MIDDAG MED KJØTT, gang/uke } \\
\hline sjeldnere enn 1 & 1 & 1 & 2 & 1 & 1 & 2 \\
\hline $1-2$ & 34 & 32 & 20 & 37 & 34 & 19 \\
\hline $3-4$ & 58 & 60 & 65 & 56 & 59 & 68 \\
\hline $5-6$ & 5 & 6 & 12 & 5 & 4 & 10 \\
\hline 7 & 1 & 1 & - & - & - & - \\
\hline ubesvart & 1 & 1 & 1 & 1 & 1 & 2 \\
\hline \multicolumn{7}{|l|}{ MIDDAG MED FISK, ganger/uke } \\
\hline sjeldnere enn 1 & 2 & 2 & 12 & 2 & 1 & 9 \\
\hline $1-2$ & 32 & 52 & 79 & 30 & 46 & 79 \\
\hline $3-4$ & 60 & 42 & 8 & 62 & 50 & 11 \\
\hline $5-6$ & 5 & 3 & - & 5 & 3 & - \\
\hline 7 & - & - & - & - & - & - \\
\hline ubesvart & 1 & 1 & 1 & 1 & 1 & 1 \\
\hline \multicolumn{7}{|l|}{ PØLSER, middager/måned } \\
\hline aldri/sjeldnere enn 1 & 22 & 13 & 10 & 25 & 15 & 14 \\
\hline $1-2$ & 43 & 41 & 42 & 45 & 44 & 45 \\
\hline $3-4$ & 28 & 38 & 40 & 24 & 35 & 36 \\
\hline $5-8$ & 3 & 4 & 5 & 2 & 2 & 3 \\
\hline 9 eller flere & 1 & 1 & 1 & - & - & 1 \\
\hline ubesvart & 3 & 3 & 2 & 4 & 4 & 3 \\
\hline \multicolumn{7}{|l|}{ KOKT FISK, middager/måned } \\
\hline aldri/sjeldnere enn 1 & 1 & 1 & 7 & 1 & 1 & 5 \\
\hline $1-2$ & 6 & 8 & 29 & 6 & 7 & 27 \\
\hline $3-4$ & 25 & 37 & 46 & 29 & 41 & 48 \\
\hline $5-8$ & 36 & 36 & 14 & 37 & 35 & 15 \\
\hline 9 eller flere & 31 & 17 & 2 & 26 & 15 & 3 \\
\hline ubesvart & 1 & 1 & 2 & 1 & 1 & 2 \\
\hline
\end{tabular}

1) Utdrag fra referanse $18-20$.

2) Sogn og Fjordane. 
Tabell 3. Noen matvaregruppers bidrag til kostens innhold av energi og enkelte næringsstoffer $\mathrm{i}$ følge kostintervju. Prosent av totalt inntak blant 190 kvinner som ble intervjuet $i$ $1982^{1}$.

\begin{tabular}{lcrrrrr}
\hline & & & & $\begin{array}{c}\text { Kost- } \\
\text { Eiber }\end{array}$ & $\begin{array}{c}\text { Kal- } \\
\text { sium }\end{array}$ & $\begin{array}{c}\text { Vitamin } \\
\text { Cnergi }\end{array}$ \\
\hline Brødvarer & 17 & 14 & 3 & 34 & 4 & 0 \\
Melk, ost & 17 & 25 & 23 & 0 & 69 & 0 \\
Smør, margarin & 10 & 0 & 27 & 0 & 0 & 0 \\
Kjøtt, fisk & 15 & 34 & 23 & 0 & 4 & 0 \\
Poteter & 8 & 4 & 0 & 19 & 3 & 17 \\
Frukt, frisk & 3 & 1 & 0 & 13 & 3 & 38 \\
Sum & 70 & 78 & 76 & 66 & 83 & 55 \\
\hline
\end{tabular}

1) Utdrag av tabell $\mathrm{V}$, referanse 11.

Gaard og medarbeidere har studert risiko for brystkreft blant dem som deltok i den andre undersøkelsesrunden. I denne analysen ble det brukt både beregnet inntak av energi og fett og de matvarene som bidro med mest fett (3). Også her var sammenhengen mellom antall kjøttmiddager per uke og øket risiko for brystkreft lineær og statistisk signifikant. I tillegg viste analysene at mer enn fem glass (0,75 liter) helmelk per dag ga økt risiko. Siden bare åtte av de 125 brystkrefttilfellene tilhørte den høyeste kategorien for bruk av helmelk ble konfidensintervallet svært stort $(1,38$, $6,14)$. Det ble ikke funnet øket risiko for dem som brukte samme mengde lettmelk eller skummet melk. Heller ikke det å tilhøre høyeste kvartil for beregnet mengde fett på brød og til matlaging økte risikoen for brystkreft. Bruk av smør og myk eller hard margarin influerte ikke på resultatet.

Beregnet inntak av energi, totalfett eller mettet fett viste ingen signifikant sammenheng med brystkreft, mens det ble funnet en statistisk signifikant, lineær og positiv sammenheng for dem som tilhørte høyeste kvartil med hensyn til inntak av enumettet fett og kreftrisiko. Dette var den eneste sammenhengen mellom kosthold og risiko for brystkreft som var signifikant både før og etter justering for energiinntak. Sammenhengen var signifikant for både pre- og postmenopausale kvinner (3).

\section{Tykktarmskreft}

Risiko for tykktarmskreft er analysert ut fra bruk av matvarer og beregnet inntak av energi, fett, kostfiber og kalsium (4). For begge kjønn ble det funnet at de som spiste pølser til middag minst fem ganger per måned hadde høyere risiko for kreft i tykktarmen enn de som ikke hadde mer enn to slike middager per måned. Denne sammenhengen var statistisk signifikant og lineær bare for kvinner. Noen sammenheng mellom totalt antall kjøttmiddager eller andre typer kjøttretter og risiko for tykktarmskreft ble ikke funnet, heller ikke i forhold til beregnet inntak av energi, fett, kostfiber eller kalsium.

\section{Kaffe og ulike typer kreft}

Stensvold og Jacobsen har analysert sammenheng mellom antall kopper kaffe per dag og forekomst av ulike typer kreft blant dem som deltok i den andre hjertekarundersøkelsen (5). De fant ingen sammenheng når de så på alle kreftformene under ett. Menn som drakk minst sju kopper kaffe per dag hadde høyere risiko for å få lungekreft og lavere risiko for kreft i munnhule og spiserør enn de som hadde et lavere forbruk av kaffe. Disse sammenhengene var statistisk signifikante også etter justering for alder, sigarettrøyking og fylke. For kvinner ble det funnet statistisk signifikant, negativ sammenheng mellom kaffeforbruk (minst fem kopper per dag sammenlignet med mindre enn fem) og risiko for ondartet føflekkreft.

\section{Lårhalsbrudd}

Meyer og medarbeideres analyse av kostens betydning for risiko for lårhalsbrudd omfattet dels bruk av drikkemelk og kaffe, og dels beregnet inntak av kalsium fra melk og ost, og av protein fra egg og de sju middagsrettene med kjøtt og fisk (6). Det ble ikke funnet noen klar sammenheng mellom bruddhyppighet og antall glass melk per dag, heller ikke mellom inntak av kalsium eller av protein fra egg, kjøtt og fisk til middag. Derimot ble det funnet en økt risiko for brudd hos de kvinner som var i høyeste kvartil for inntak av "animalsk protein minus protein fra melk" og i laveste kvartil for inntak av kalsium, sammenlignet med dem som tilhørte de øvrige kvartilene. I tillegg ble det funnet at kvinner som drakk minst ni kopper kaffe per dag hadde statistisk signifikant økt risiko for lårhalsbrudd, men her ble det ikke funnet noen lineær sammenheng for lavere inntak.

\section{DISKUSJON}

Flere forskere har brukt kostholdsdataene fra hjertekarundersøkelsens tre pilotfylker til analyser av risiko for brystkreft (1-3,5), tykktarmskreft (4) og lårhalsbrudd (6). Analyser av kosthold og risiko for flere andre kreftformer er i gang (Veierød, personlig meddelelse). Det ble funnet statistisk signifikante sammenhenger mellom svar på enkelte av kostspørsmålene eller estimerte inntak av enkelte næringsstoffer og sykdomsrisiko (tabell 4). Siden mange matvarer, næringsstoffer og sykdommer er blitt testet, kan det ikke utelukkes at noen av disse sammenhengene var tilfeldige. Men bortsett fra Vattens funn om hyppig bruk av kokt fisk til middag og redusert risiko for brystkreft (2) og Stensvolds funn om stort kaffeforbruk og redusert risiko for ondartete føflekker (5), er de omtalte resultatene funnet også i andre prospektive studier av risiko for kreft. Gaards arbeid føyer seg inn i rekken av prospektive studier som ikke kan påvise sammenheng mellom høyt fettinnhold i kosten og økt risiko for brystkreft (21). Meyers funn er særlig 
Tabell 4. Oversikt over noen resultater fra studiene av sammenheng mellom kosthold og sykdomsrisiko.

\begin{tabular}{lll}
\hline Sykdom & Kostkomponenter - økt risiko & RR (95\% CI) \\
\hline Brystkreft (Vatten et al. 1990 (1)) & $\geq 5$ kopper kaffe/dag + BMI $<24 \mathrm{~kg} / \mathrm{m}^{2}$ & $0,4(0,2-0,8)$ \\
Brystkreft (Vatten et al. 1990 (2)) & $\geq 5$ middager med kjøtt/uke & \\
& $\geq 5$ middager med kokt fisk/måned & $1,8(1,1-3,1)$ \\
& $\geq 5$ glass helmelk/dag & $0,7(0,4-1,0)$ \\
Brystkreft (Gaard et al. 1995 (3)) & $\geq 5$ middager med kjøtt/uke & $2,9(1,4-6,1)$ \\
& Høyt inntak av enumettet fett, energijustert & $2,3(1,3-4,0)$ \\
& $\mathrm{K}^{2}: \geq 5$ middager med pølse/måned & $1,7(1,2-2,5)$ \\
Tykktarmskreft (Gaard et al. 1996 (4)) & & $3,5(1,02-11,9)$ \\
Ulike typer kreft (Stensvold et al. 1994 (5)) & & \\
$\quad$ munnhule- og spiserørkreft & M: $\geq 7$ kopper kaffe/dag & 0,5 \\
lungekreft & M: $\geq 7$ kopper kaffe/dag & $1,5(1,0-2,3)$ \\
$\quad$ ondartet føflekkkreft & K: $\geq 5$ kopper kaffe/dag & $0,5(0,3-0,9)$ \\
Lårhalsbrudd (Meyer et al. 1997 (6)) & K: Lavt inntak av kalsium + høyt inntak av & $2,0(1,1-3,6)$ \\
& $\begin{array}{l}\text { animalsk protein minus protein fra melk } \\
\text { K: } \geq 9 \text { kopper kaffe/dag }\end{array}$ & $1,9(1,1-3,2)$ \\
\hline
\end{tabular}

1) $\mathrm{RR}(95 \% \mathrm{CI})=$ relativ risiko $(95 \%$ konfidensintervall). Analysene er justert for alder og andre relevante kovariabler som var tilgjengelig i materialet (1-6).

2) $\mathrm{K}=$ kvinner, $\mathrm{M}=$ menn.

interessant fordi det kan knyttes til en hypotese om virkning av metabolsk syre på beinvev (22).

I de multivariate analysene ble det kontrollert for det som var tilgjengelig av andre relevante risikofaktorer, så som alder, kroppshøyde, kroppsmasse og røyking. Hjerte-karundersøkelsene omfattet naturlig nok ikke alle forhold av betydning for de unders $ø$ kte typene av kreft eller for lårhalsbrudd. Resultatene kan derfor bare antyde mulige sammenhenger, og det kan ikke utelukkes at det ligger andre faktorer bak de identifiserte kostvanene. For eksempel kan høyt forbruk av pølser til middag være en indikator på en spesiell levemåte (23). Pølser er lettvint mat og blir ofte spist uten tillegg av grønnsaker (24), noe som kan føre til lavt inntak av spesielle typer kostfiber, $\beta$ karoten og andre antioksidanter. Dette er stoffer som i flere andre studier er funnet å kunne beskytte mot tykktarmskreft (25), men som vårt spørreskjema ikke kan si noe om. Også den påviste sammenhengen mellom høyt kaffekonsum og økt risiko for lungekreft hos menn kan skyldes konfundering, i det flere norske studier har vist at både røykere og de som drikker mye kaffe har et lavere forbruk av frukt og grønnsaker enn ikke-røykere og personer som ikke drikker eller drikker lite kaffe $(26,27)$.

Den gang spørreskjemaet ble laget, var hovedmålet å skaffe data som kunne bidra til å forklare forskjeller i konsentrasjon av serumkolesterol blant deltakerne (28). Selv om fett var dominerende kostholdshypotese på den tiden, ble det også tatt med en del andre spørsmål av mer generell interesse. Spørsmålene ble formulert ut fra den viten vi hadde om norsk kosthold fra detaljerte kostholdsundersøkelser i forholdsvis små grupper i befolkningen (29), og ut fra de erfaringer Bjelke hadde gjort med bruk av postale spørreskjemaer (30). Det ble lagt stor vekt på at spørsmålene skulle være lette å besvare, noe den høye svarprosenten og den lave andelen med ubesvart for de fleste spørsmålene tydet på.

Reproduserbarhetstestingen viste godt samsvar for de fleste kostspørsmålene. At svarene på bruk av leverpostei, appelsiner og kjøpt eller hjemmebakt brød varierte noe kan forklares med at dette er matvarer som gjerne blir spist i perioder. Bruk av appelsiner har for eksempel vist seg å variere i forhold til den måned hjerte-karundersøkelsen fant sted (17), noe som kan tyde på at en svarer ut fra det en gjør i øyeblikket, selv om spørsmålene gjelder hva en vanligvis gjør.

I epidemiologiske studier er det viktigere å kunne rangere personene etter grad av eksposisjon enn å finne det absolutte inntaket av mulige skadelige eller forebyggende komponenter i kosten. Inndeling i objektive svarkategorier for porsjonsstørrelse eller hyppighet $\mathrm{i}$ bruk av matvarer gir mulighet til å identifisere grupper med klart forskjellig inntak. Svarkategoriene i spørreskjemaet skilte ikke alltid deltakerne like godt (tabell 2). Dette gjaldt særlig spørsmålene om bruk av kjøtt og fisk til middag per uke blant begge kjønn, og antall brødskiver per dag og mengde smør eller margarin per brødskive blant kvinner. Variasjonen i forbruk ble fanget opp bedre for spesielle typer middagsretter som pølser og kokt fisk. Det var også 
god svarfordeling for begge kjønn når det gjaldt hvor mye melk og kaffe som ble drukket per dag.

Beregning av kostens innhold av energi og næringsstoffer ble opprinnelig ansett som urealistisk. Spørsmålene var ikke særlig detaljerte med hensyn til typer av mat, få spørsmål gikk på mengde og de dekket heller ikke alle sider av deltakernes vanlige kosthold. At beregnet inntak fra spørreskjemadataene svarte til $70-80 \%$ av gjennomsnittlig innhold i kostintervjuet kan tyde på at skjemaet gir et godt bilde av deltakernes kosthold med hensyn til innhold av energi, protein, fett og kalsium, samt forbruk av brød, melk og smør/margarin. Analyser av endring i inntak av mettet fett fra smør, margarin og melk i forhold til endring i serumkolesterol hos menn som deltok i første og andre hjerte-karundersøkelse i Oppland eller i andre og tredje undersøkelse i Finnmark $(31,32)$, bør også kunne tolkes som at skjemaet gir brukbar informasjon om fettinnholdet i deltakernes kosthold. Et annet mål for skjemaets validitet kan være Thune og medarbeideres påviste sammenheng mellom beregnet inntak av energi og fysisk aktivitet $i$ arbeid og fritid (33).

Frisk frukt og poteter ga i følge næringsberegning av kostintervjuet ca $55 \%$ av samlet mengde vitamin C, mens beregning av svar på spørreskjemaspørsmålene om poteter og appelsiner bare utgjorde ca $35 \%$ av total mengde vitamin C i intervjuet. Skjemaet fanget med andre ord ikke opp mer enn en tredel av tilførselen av dette vitaminet. I tredje runde av hjerte-karundersøkelsene ble det inkludert et par spørsmål om grønnsaker og frukt, men om dette er tilstrekkelig til å kunne beskrive deltakernes inntak av kostfiber, $\beta$-karoten, vitamin $\mathrm{C}$ og andre antioksidanter er ikke undersøkt.
Spørreskjemaet er heller ikke detaljert nok til å kunne si noe særlig om deltakernes bruk av alkohol, fet fisk og andre typer av kosttilskudd enn tran.

Kostholdsdataene fra de tre pilotfylkene omfatter en stor og veldefinert populasjon, og kan derfor være interessante ikke bare for analyse av risiko for hjertekarsykdom, men også for andre sykdommer der en antar at kostholdet spiller en rolle for utviklingen. Materialet omfatter en forholdsvis ung kohorte etter som de fleste typer kreft, lårhalsbrudd og andre velstandssykdommer først blir vanlige i 60-70 års alderen. Selv 23 år etter at hjerte-karundersøkelsene startet, er det fortsatt bare de aller eldste deltakerne som har fylt 70 år. I flere av studiene er det pekt på at 10-11 års oppfølgingstid kanskje ikke var lenge nok til å gi tilstrekkelig antall tilfeller til å avsløre eventuelle sammenhenger $(4,5)$. Bruk av kostholdsdataene til analyse av risiko for sykdom eller død forutsetter derfor ikke bare at sykdommen eller dødsårsaken antas å ha sammenheng med en eller flere av de kostkomponenter som skjemaet omfatter, den må i tillegg være så vanlig at beregning av statistisk styrke gir håp om å kunne påvise en slik sammenheng.

En stor fordel med dette materialet er at mange har besvart de samme spørsmålene to eller tre ganger med flere års mellomrom. Dette gir ikke bare muligheter til å analysere utfall for grupper som har endret kostvanene sine i positiv eller negativ retning $(31,32)$, men også hos grupper med stabile, men klart forskjellige matvaner (34). Ved vurdering av resultatene må en imidlertid alltid ta hensyn til at spørreskjemaet ikke omfattet det totale kostholdet.

\section{REFERANSER}

1. Vatten LJ, Solvoll K, Løken EB. Coffee consumption and the risk of breast cancer. A prospective study of 14,593 Norwegian women. Br J Cancer 1990; 62: 267-70.

2. Vatten LJ, Solvoll K, Løken EB. Frequency of meat and fish intake and risk of breast cancer in a prospective study of 14,500 Norwegian women. Int J Cancer 1990; 46: 12-5.

3. Gaard M, Tretli S, Løken EB. Dietary fat and the risk of breast cancer: A prospective study of 25,892 Norwegian women. Int $J$ Cancer 1995; 63: 13-7.

4. Gaard M, Tretli S, Løken EB: Dietary factors and risk of colon cancer: a prospective study of 50.535 young Norwegian men and women. Eur J Cancer Prev 1996; 5: 445-54.

5. Stensvold I, Jacobsen BK. Coffee and cancer: a prospective study of 43,000 Norwegian men and women. Cancer Causes Control 1994; 5: 401-8.

6. Meyer HE, Pedersen JI, Løken EB, Tverdal A. Dietary factors and the incidence of hip fracture in middleaged Norwegians. Am J Epidemiol 1997; 145: 117-23.

7. Bjartveit K, Foss OP, Gjervig T, Lund-Larsen PG. The cardiovascular disease study in Norwegian counties. Background and organisation. Acta Med Scand 1979; suppl. 623.

8. Løken EB, Solvoll K. The reproducibility of a self-administered diet questionnaire. Vår Föda 1987; Suppl 1: 33-7.

9. Løken EB, Solvoll K, Lund-Larsen K, Hardeng S. Noen resultater fra kostholdsintervjuer i ulike distrikter. Intern rapport til Helsedirektoratet, Avd. for kostholdsforskning, Universitetet i Oslo. Oslo, 1978. 
10. Solvoll K. Sammenlikning av kostholdsdata fra selvadministrert spørreskjema og 24 timers recall. Forskningsresultater fra Avdeling for kostholdsforskning, melding 31. Oslo, 1983.

11. Solvoll K, Løken EB, Grønn M, Andersson E. Kosthold i Vestre Toten 1982. Resultater fra $24 \mathrm{~h}$ recall blant menn og kvinner 25-54 år. AKF tabellrapport nr. 2. Oslo, 1985.

12. Blaker B, Solvoll K, Lund-Larsen K. Kosthold i Vestre Toten 1987. Resultater fra $24 \mathrm{~h}$ recall blant menn og kvinner 30-59 år. AKF tabellrapport nr. 6. Oslo, 1988.

13. Blaker B, Rimestad AH. Matvaretabell. 6. reviderte utgave. Statens ernceringsråd. Oslo, 1991.

14. Gaard M, Sandvin O, Løken EB. Calculation of nutrient intake based on dietary data from the 2nd cardiovascular disease survey in Finmark, Sogn og Fjordane and Oppland 1977-83. Technical report 1 - 1996. The Cancer Registry of Norway, Inst. Epid. Cancer Res. Oslo, 1996.

15. Solvoll K. Data om kosthold i Alta. Resultater fra spørreskjema. Fra Avdeling for kostholdsforskning 1976; 3.

16. Hardeng S, Solvoll K. Data om kosthold i åtte kommuner i Sogn og Fjordane. Resultater fra spørreskjema. Fra Avdeling for kostholdsforskning 1978; 2.

17. Løken EB, Solvoll K, Hardeng S. Data om kosthold i Oppland. Resultater fra spørreskjema 1976-78. Forskningsresultater fra Avdeling for kostholdsforskning Melding nr. 24, 1980.

18. Løken EB. Kosthold i Finnmark 1977-78. Resultater fra spørreskjema. Forskningsresultater fra Avdeling for kostholdsforskning Melding nr. 32, 1983.

19. Løken EB, Solvoll K. Kosthold i Sogn og Fjordane 1980. Resultater fra spørreskjema. AKF tabellrapport nr. $1,1985$.

20. Løken EB, Solvoll K. Kosthold i Oppland 1981-83. Resultater fra spørreskjema. AKF tabellrapport nr. 5, 1987.

21. Colditz G, DeJong W, Hunter D, Trichopoulos D, Willett W. Harvard report on cancer prevention. Volume 1: Causes of human cancer. Cancer Causes and Control 1996; 7: supplement.

22. Metz JA, Anderson JJ, Gallagher PN Jr. Intakes of calcium, phosphorus and protein, and physical activity level are related to radial bone mass in young adult women. Am J Clin Nutr 1993; 58: 537-42.

23. Hellevik O. Nordmenn og det gode liv. Norsk monitor 1985-1995. Universitetsforlaget. Oslo, 1996.

24. Løken EB. Middagsmåltidet - vaner og ernæringsmessig betydning. Fra Avdeling for kostholdsforskning 1976; 1: 1-11.

25. Potter JD, Slattery ML, Bostick RM, Gapstur SM. Colon cancer: a review of the epidemiology. Epidemiol Rev 1993; 15: 499-545.

26. Jacobsen BK, Thelle DS. The Tromsø Heart Study: Is coffee drinking an indicator of a life style with high risk for ischemic heart disease? Acta Med Scand 1987; 222: 215-21.

27. Trygg K, Lund-Larsen K, Sandstad B, Hoffman HJ, Jacobsen G, Bakketeig LS. Do pregnant smokers eat differently from pregnant non-smokers? Paediatr Perinatal Epidemiol 1995; 9: 307-19.

28. Solvoll K, Selmer R, Løken EB, Foss OP, Trygg K. Coffee, dietary habits and serum cholesterol among men and women 35-49 years of age. Am J Epidemiol 1989; 129: 1277-88.

29. Øgrim ME, Nes I. Hva vet vi om norsk kosthold? Näringsforskning 1978; 22: 256-64.

30. Bjelke E. Epidemiologic studies of cancer of the stomach, colon, and rectum; with special emphasis on the role of diet. Volume 2: Methods of migrant and dietary studies, mail survey results on diet in Norway and the United States. Doctoral thesis, University of Minnesota, 1973.

31. Løken EB, Solvoll K. Five-year changes in dietary habits and serum concentrations of cholesterol in healthy Norwegians aged 35-49 years. The Oppland County Study. Circulation 1990; 82: 511.

32. Løken EB, Solvoll K, Drevon CA. Kostholdsdata i fylkesundersøkelsene. Norsk Epidemiologi 1993; 3: 7-8.

33. Thune I, Brenn T, Lund E, Gaard M. Physical activity and the risk of breast cancer. N Engl J Med 1997; 336: $1269-75$.

34. Ocké MC, Bueno-de-Mesquita HB, Feskens EJM, van Staveren WA, Kromhout D. Repeated measurements of vegetables, fruits, $\beta$-carotene, and vitamins $\mathrm{C}$ and $\mathrm{E}$ in relation to lung cancer. The Zutphen study. Am $J$ Epidemiol 1997; 145: 358-65. 
Vedlegg. Kostholdsspørreskjema benyttet i andre runde av hjerte-karundersøkelsene i Finnmark, Sogn og Fjordane og Oppland.
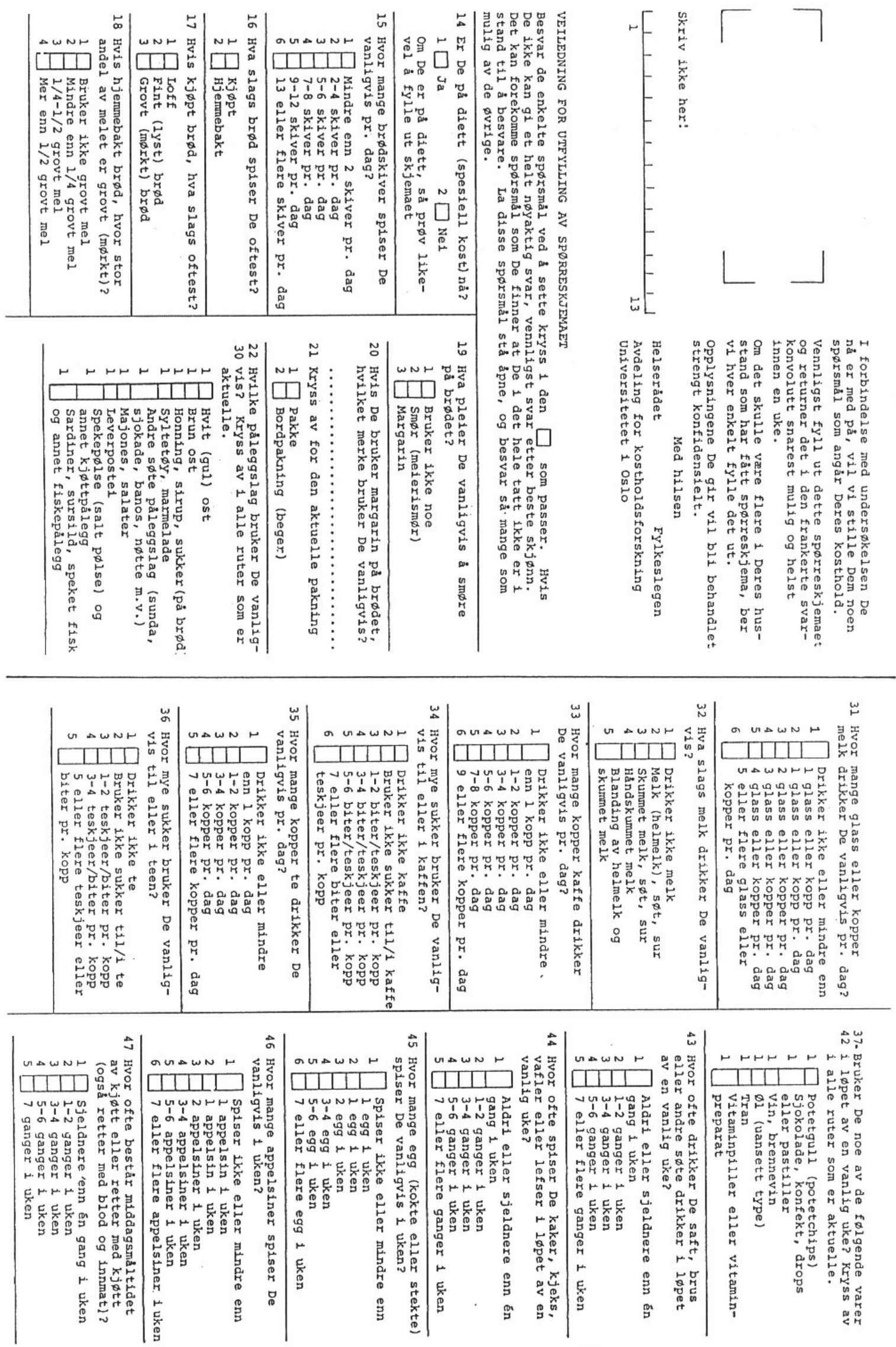
Vedlegg (fortsatt). Kostholdsspørreskjema benyttet i andre runde av hjerte-karundersøkelsene i Finnmark, Sogn og Fjordane og Oppland.
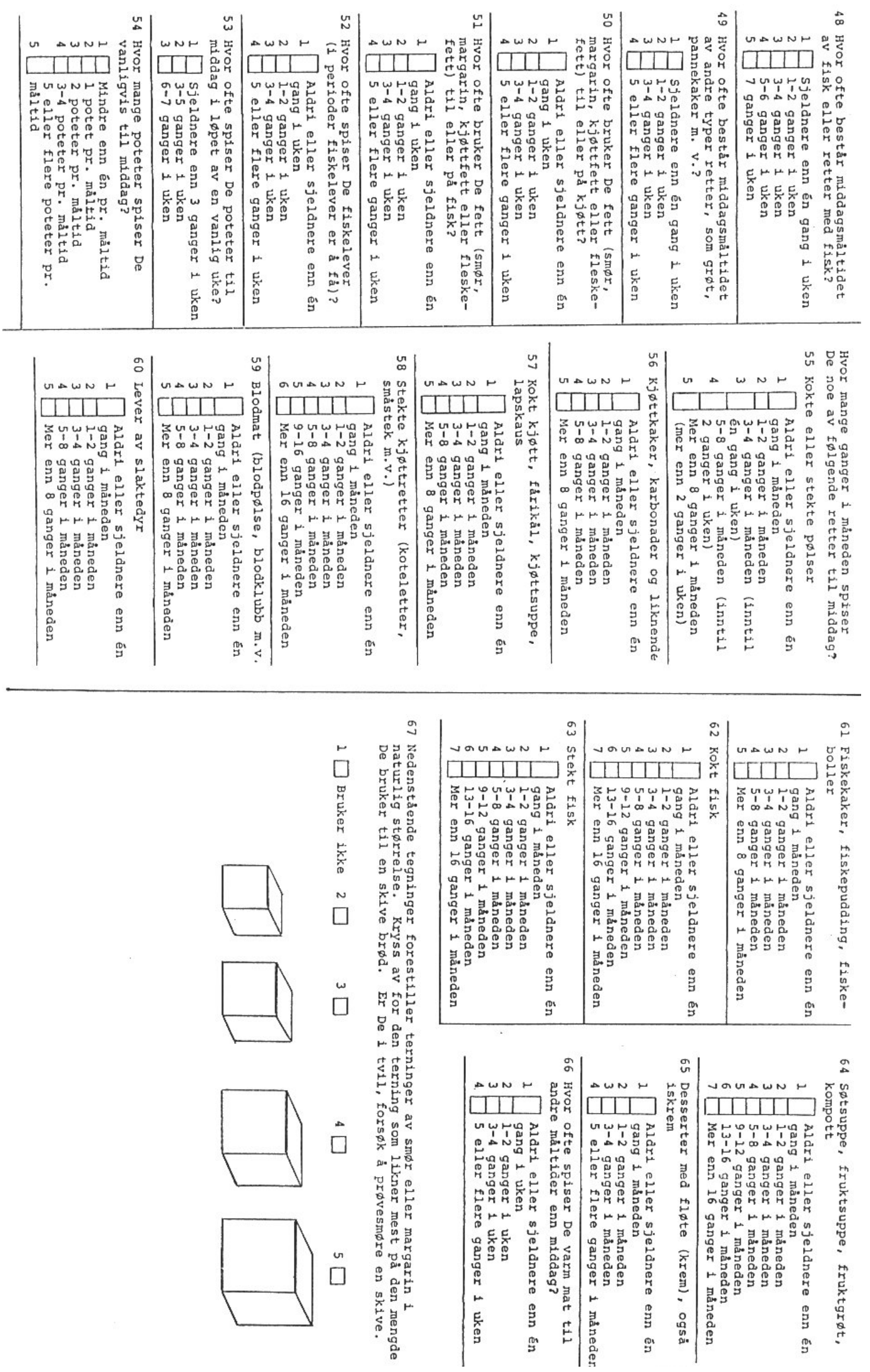